\title{
Mažos galios biokuru kūrenamų vandens šildymo katilų veikimo parametrų tyrimas
}

\author{
Tomas Vonžodas, \\ Nerijus Pedišius, \\ Mantas Valantinavičius \\ Lietuvos energetikos institutas, \\ Šiluminių ìrengimu tyrimo \\ ir bandymu laboratorija, \\ Breslaujos g. 3, LT-44403 Kaunas \\ El.paštas: testlab@mail.lei.lt
}

\begin{abstract}
Eksperimentiškai tirti ịvairiais principais veikiančių mažos galios vandens šildymo katilų, kūrenamų medienos kuru, efektyvumas ir tarša. Parodyta, kad granuliuoto kuro naudojimas mažos galios ịrenginiuose leidžia pasiekti ne mažesnį kaip 90 \% naudingumo koeficientą ir ị aplinką išmetama mažiausiai teršalų. Malkinès medienos naudojimo periodiškai ịkraunamuose katiluose efektyvumas labai priklauso nuo tinkamos degimo kameros konstrukcijos, antrinio oro tiekimo vietos parinkimo, temperatūrinio režimo palaikymo. Labiausiai oro tiekimo reguliavimas reikalingas ịdegant naujai įkrautą kurą ir baigiantis ịkrovos degimui. Atvirkštinio deginimo principas, kuriame siekiama išnaudoti kuro dujinimo ir gautų dujų deginimo pranašumus, leidžia pasiekti geresnių efektyvumo rodiklių ir mažesnių teršalų emisijų, bet reikalauja tinkamos konstrukcijos degimo kameros ir efektyvaus antrinio oro tiekimo, kad būtų užtikrintas visiškas sudegimas.

Taip pat atliktas skaitinis antrinio oro tiekimo ị apatinio degimo katilo kūryklą esant natūraliai traukai modeliavimas, leidžiantis parinkti tinkamiausias oro tiekimo vietas ir kūryklos konstrukciją bei analizuoti srautų maišymosi procesus.
\end{abstract}

Raktažodžiai: biokuras, medienos kuras, vandens šildymo katilai, efektyvumas, teršalai

\section{IVADAS}

Didžiąją dalį atsinaujinančių energijos išteklių sudaro kietasis biokuras: ịvairių rūšių mediena, šiaudai ir kita augalinè biomasè, kuri gali būti panaudota energijos gamybai. Tačiau pagrindiniu ir plačiausiai naudojamu namų ūkiuose ir katilinėse kuru yra mediena, nes jos ištekliai yra didžiausi, ji lengviausiai prieinama ir, jei nekreiptume demesio i jos panaudojimo efektyvumą bei keliamą taršą, nereikalauja sudètingos įrangos ir paruošimo. Lietuvoje šio kuro potencialas vis dar nèra pakankamai tiksliai ịvertintas ir gali siekti $1000-1050$ ktne arba 4,85-5,93 mln. $\mathrm{m}^{3}$ medienos. Šiuo metu jau panaudojama apie $910 \mathrm{ktne}$ [1]. Pastaruosius 20 metu medienos kuro naudojimas nuolatos augo, didèjo šio kuro paklausa namų ūkyje būstui šildyti ir maistui ruošti, daugiau jo sunaudojama centralizuoto šildymo ka- tilinėse. $2011 \mathrm{~m}$. duomenimis [1], namų ūkiuose buvo naudojama apie $61,3 \%$ bendrojo medienos kuro kiekio, centralizuoto šildymo katilinėse ir kogeneracinèse elektrinèse atitinkamai 19,5\% ir $6 \%$. Likę kiekiai šildymui ir technologiniams procesams buvo sunaudoti pramonès, paslaugų ir žemès ūkio sektoriuose.

Biokuro naudojimas sparčiai auga ne tik naujai ịrengtose šildymo sistemose, bet ir mažiau efektyviose senose, kuriu visi efektyvumo ir taršos parametrai yra daug blogesni. Lietuvoje apie $90 \%$ namu ùkiu turi techniškai pasenusias šildymo sistemas, kurias reiktų renovuoti. Šios šildymo sistemos, palyginti su naujosiomis sistemomis, išmeta ị aplinką daug teršalu, pvz., anglies monoksido (CO), lakiuju organinių junginių (LOJ), kietujjų dalelių (KD) bei policiklinių aromatinių angliavandenilių (PAA). Visi šie teršalai didina fonini gyvenamųjų rajonų, apšildomų biokuru, užterštumą, 
ypač šildymo sezono metu, o užterštumas kietosiomis dalelèmis KD10 (kietosios dalelès, kurių skersmuo $<10 \mu \mathrm{m}$ ) labai dažnai viršija leidžiamąsias koncentracijas.

Taigi didejjant biokuro naudojimui namų ūkiuose tampa akivaizdu, kad būtina diegti naujas modernias ir mažiau teršiančias biokuru kūrenamas šildymo sistemas, jomis pakeisti senąsias. Tik taip galima išvengti didëjančios aplinkos taršos.

Sprendžiant šias problemas reikètų remtis Austrijos, Vokietijos, Švedijos, Suomijos ir Danijos patirtimi. Šiose šalyse jau kelis dešimtmečius skiriamas didelis dėmesys biomasės terminio skaidymo sistemų technologinei pažangai ir yra pasiektą įspūdingų rezultatų, ypač taršos mažinimo srityje. Pagrindinis šiose šalyse atliekamų mokslo tyrimų tikslas - sukurti mažos taršos, taip vadinamosios „nulinès taršos", biomasès terminio skaidymo sistemas panaudojant ivvairius technologinius sprendinius [2]. Vystant šias technologijas pagrindinis dèmesys sutelkiamas ị:

- naujų biokuro rūšių ir mišinių tyrimus bei tinkamą jų pritaikymą įrenginiams;

- biomasės deginimo technologijų tyrimus mažos, vidutinès ir didelès galios jègainèse [3];

- naujų inovatyvių sistemų, veikiančiu kombinuotu ciklu, kūrimą ir tobulinimą;

- priemonių degimo produktams valyti kūrimą ir tobulinimą [4];

- biomasès dujinimo ir pirolizès technologijų tyrimus;

- terminio skaidymo procesų ir irenginių automatinio valdymo sistemų tobulinimą ir diegimą.

Būtina pabrèžti, kad nors sparčiai vystomos naujos biomasès panaudojimo energijai gaminti technologijos, tiesioginis biokuro deginimas dar ilgai išliks pagrindiniu būdu šilumos ir netgi elektros energijai gaminti mažos ir vidutinès galios ịrenginiuose. Europos šalyse vystomi moksliniai ir taikomieji darbai bei teisinių priemonių, skatinančių biokuro naudojimą, rengimas bei diegimas patvirtina problemos ilgalaikę svarbą ir gali būti tinkamu orientyru sprendžiant Lietuvoje apsirūpinimo šilumos energija problemas.

Toliau šiame straipsnyje išsamiau nagrinėsime tik du uždavinius:

- biokuro ịprastinio deginimo efektyvumo didinimą panaudojant kitų rūšių biokurą ir jų mišinius bei granuliuotą biokurą;

- degimo produktų ir tiekiamo degimui oro maišymosi procesų intensyvinimą tobulinant degimo kameras ir taikant pakopinị oro tiekimą.

\section{REIKALAVIMAI BIOKURO DEGINIMO IRENGINIAMS}

Lietuvoje iki šiol pagrindinis dèmesys buvo sutelktas ị vidutinès ir didelès galios katilų, kūrenamų biokuru, įrengimą ir tobulinimą siekiant pakeisti iškastinị kurą vietiniu kuru ir kuo sparčiau mažinti priklausomybę nuo iškastinio kuro importo. Nuo 1993 m., kai biokuras pradètas naudoti centralizuoto šildymo katilinèse, irengtų katilų bendroji instaliuotoji galia padidèjo iki 650 MW. Tačiau kietojo biokuro naudojimas energijos gamybai sparčiai augo ne tik centralizuoto šildymo katilinèse, bet ir namų ūkiuose, kaimo vietovėse bei miestų privačių namų rajonuose. Statistiniai duomenys patvirtina, kad biokuras didžiąa dalimi vis dar naudojamas namų ūkiuose.

Tenka pripažinti, kad Lietuvoje gaminamų mažos ir vidutinès galios katilų technologinei pažangai buvo skiriamas mažokas dèmesys. Tik atskiri stambesni gamintojai, siekiantys palaikyti savo gaminių konkurencingumą kitu ES šalių rinkose, skyrè dèmesį moksliniams tyrimams ir bandymus. Taip pat nebuvo skiriamas reikiamas demesys teisinèms priemonèms, skatinančioms gamintojus siekti aukščiausių energetinių rodiklių, ir juos nustatyta tvarka patvirtinti. Techniniai reglamentai nenumate vandens šildymo katilų, skirtų pastatams šildyti ir kūrenamų biokuru, reikalavimų efektyvumui ir periodiniam jo tikrinimui.

Pastaraisiais metais ši padètis keičiasi, nes Lietuvoje gaminamiems katilams pradètos taikyti privalomosios atitikties vertinimo standarto LST EN 303-5:2012 [5] reikalavimams procedūros. Tiesa, šios procedūros neapima visu standarto reikalavimų, tačiau vis dèlto verčia gamintojus tobulinti katilus siekiant geresnių efektyvumo ir taršos rodiklių.

Atsižvelgus ị tai, būtina neatidèlioti ir tęsti teisinės bazès kūrimą siekiant:

- nustatyti vieningus reikalavimus biokurui klasifikuoti ir jo kokybės rodikliams vertinti;

- nustatyti vieningus reikalavimus katilų efektyvumui ir jų bandymams;

- taikyti privalomąsias ir skatinamąsias priemones gamintojams, gaminantiems aukštesnio efektyvumo katilus.

Pirmajam uždaviniui išspręsti jau parengti ir ịteisinti standartai, kurie sunormina kietojo biokuro klasifikavimą [6], sudaro pagrindą vienodinti reikalavimus jo kokybès rodikliams vertinti ir sąlygas kuro rinkoje.

Antrasis uždavinys sprendžiamas vadovaujantis standartu [5], kuris nustato kietuoju kuru kūrenamiems katilams reikalavimus, nurodytus 1 lentelëje.

Trečiasis uždavinys sprendžiamas taikant reikalavimus, kuriuos reglamentuoja bendrosios nuostatos dèl katilų efektyvumo didinimo ir teršalų emisijų i aplinką mažinimo, ir taip pat nacionalines priemones, pvz., Danijoje skatinamos išmokos individualių namų gyventojams, įsigyjantiems ne žemesnès kaip 3 klasès katilus.

Kai kurios šalys jau senokai pasiekè geresnius naudingumo koeficiento rodiklius, pvz., Austrija (1 pav.). Šie duomenys parodo, kad kietuoju kuru kūrenamų katilų naudingumo koeficiento vidurkis pasiekè $90 \%$ ir labai sumažèjo jo sklaida, kuri dar $1990 \mathrm{~m}$. geriausiu atveju sudare $80 \pm 10 \%$, o 2000 m. - $90 \pm 5 \%$. Tai patvirtina itin išaugusị kietojo 
1 lentelè. Naudingumo koeficiento reikalavimai pagal [5]

\begin{tabular}{|c|c|c|c|c|}
\hline Katilo klasė & Taikomas standartas & Katilo galia kW & Naudingumo koeficientas \% & Naudingumo koeficiento formulè \\
\hline \multirow{2}{*}{5} & \multirow{2}{*}{ LST EN 303-5: 2012} & 10 & 88 & \multirow{2}{*}{$\eta=87+\log Q_{n}$} \\
\hline & & 300 & 89 & \\
\hline \multirow{2}{*}{4} & \multirow{2}{*}{ LST EN 303-5: 2012} & 10 & 82 & \multirow{2}{*}{$\eta=80+2 \log Q_{n}$} \\
\hline & & 300 & 84 & \\
\hline \multirow{2}{*}{3} & \multirow{2}{*}{ LST EN 303-5: 2012} & 10 & 73 & \multirow{2}{*}{$\eta=67+6 \log Q_{n}$} \\
\hline & & 300 & 82 & \\
\hline \multirow{2}{*}{2} & \multirow{2}{*}{ LST EN 303-5: 2000} & 10 & 63 & \multirow{2}{*}{$\eta=57+6 \log Q_{n}$} \\
\hline & & 300 & 72 & \\
\hline \multirow{2}{*}{1} & \multirow{2}{*}{ LST EN 303-5: 2000} & 10 & 53 & \multirow{2}{*}{$\eta=47+6 \log Q_{n}$} \\
\hline & & 300 & 62 & \\
\hline
\end{tabular}

Pastaba. $Q_{n}$ - katilo vardinè galia $k W$.

kuro panaudojimo efektyvumą. Tačiau taip pat matyti, kad tolesni naudingumo koeficiento didinimo tempai labai sumažèja. Reikia laikyti, kad dabar priartèta prie situacijos, kai efektyvumas gali būti padidintas tik labai tikslingomis ir tyrimais pagrịstomis priemonemis, ịvertinus tokių priemonių ekonominị tikslingumą.

Apžvelgus bendrąją padèti, galima teigti, kad naudingumo koeficiento gerinimą ir teršalų emisijų mažinimą apsunkina ịprastinio (neparuošto) kietojo kuro deginimo mažuose įrenginiuose ypatumai:

- degimo proceso reguliavimas sudètingas dèl jo inertiškumo ir oro degimui tinkamo tiekimo;

- vandens temperatūros reguliavimas ir periodinès ịkrovos, jei tokios daromos, sukelia degimo proceso nestabilumus, kurie pasireiškia emisijų padidèjimu, palyginti su nusistovejusiu procesu;

- medienos kuro (malkos, granulès, briketai, mišiniai...) rūšių ir jo savybių ịvairovė;

- katilų tipų įvairovè.

Labai pagerina degimo procesą ir jo reguliavimą išankstinis kietojo kuro paruošimas, pvz., granulių ar briketų gamyba. Tai leidžia automatizuoti taip paruošto kuro tiekimą i degimo kamerą ir priartinti jo deginimą prie dujinio ar skystojo kuro deginimo proceso [8].

Reikia atkreipti dėmesị dar ị vieną svarbų požymį, kuris pasireiškia kūrenant katilus kietuoju kuru, - tai labai netolygūs emisijų išmetimai ị aplinką dẻl nuolat kintančio degimo proceso intensyvumo, kurị lemia periodinès kuro ịkrovos ir netolygus degimas dèl ịkrovos pasikartojančių sukritimų. Kadangi to negalima išvengti, būtina nustatyti emisijų matavimo tvarką vykdant tokių katilų veikimo kontrolę.

\section{TYRIMO İRANGA IR METODAI}

\section{Eksperimentiniai tyrimai}

Kietojo biokuro deginimo ypatumai ịveda savituosius reikalavimus įrenginių tyrimams ir reikalauja sudètingos šiuolaikiškos įrangos bei aparatūros, kuri leistų vykdyti veikimo parametrų ir pagrindinių $\mathrm{CO}, \mathrm{NO}_{\mathrm{x}}, \mathrm{C}_{\mathrm{x}} \mathrm{H}_{\mathrm{y}}$ emisijų nuolatinị matavimą, registravimą ir skaičiavimą. Tyrimo metu tokie matavimo rezultatai turi būti registruojami ganètinai dideliu dažniu (rekomenduojama kas $20 \mathrm{~s}$ ) viso tyrimo metu. Tyrimo etapo pabaigoje atliekamas surinktų rezultatų vidutinių verčių nustatymas.

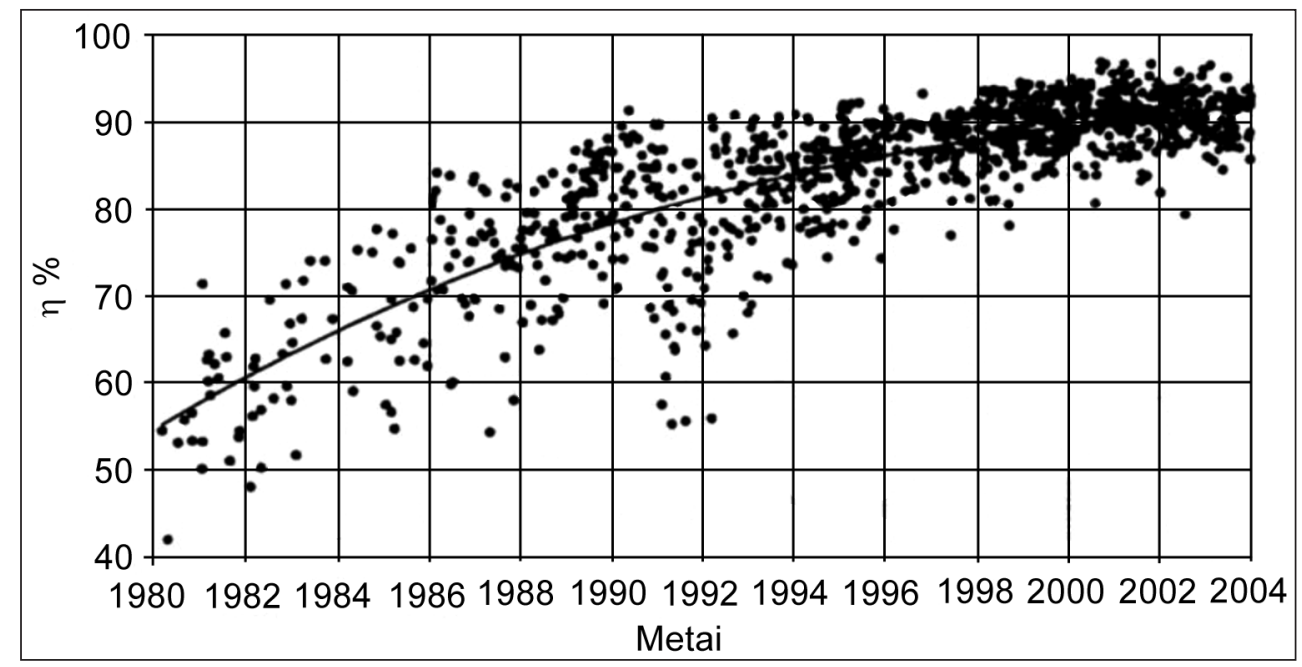

1 pav. Kietojo kuro katilu, naudojamų Austrijoje [7], naudingumo koeficiento gerinimo statistiniai duomenys 


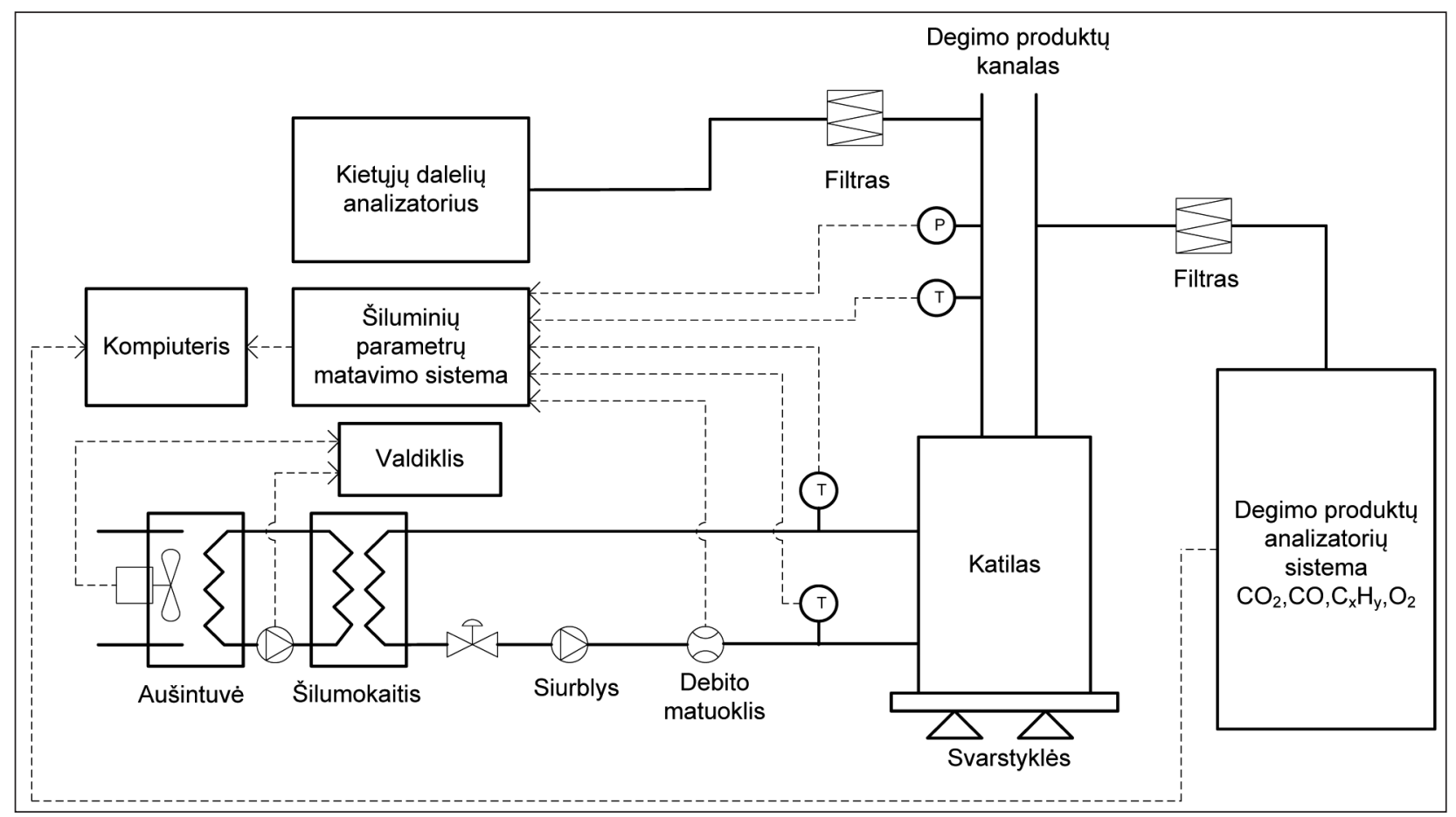

2 pav. Vandens šildymo įrenginių ir prietaisų veikimo eksperimentinių tyrimų įrangos bendroji schema

Eksperimentiniai tyrimai buvo atliekami įrenginyje, kurio schema pateikta 2 pav. Tyrimų įrenginị sudaro:

- biokuro ịkrovos suvartojimo sekimo ir matavimo sistema, kurioje tiriamasis objektas su biokuro ịkrova ịrengiamas ant elektroninių svarstyklių, užtikrinančių kuro suvartojimo matavimus su \pm 20 g neapibrèžtimi;

- šilumnešio cirkuliacijos valdymo ir jo parametrų matavimo sistema, kuri igalina įvertinti tiriamojo katilo naudingai perduodamą šilumą su $\pm 1,5 \%$ neapibrèžtini;

- degimo dujų komponenčių matavimo sistema, leidžianti atlikti atskirų dujų komponenčių matavimus su $\pm 2 \%$ neapibrèžtimi;

- kietųur dalelių koncentracijos gravimetriniu metodu matavimo ịranga, leidžianti ịvertinti kietųjų dalelių koncentracijas su $\pm 2 \%$ neapibrèžtimi;

- pagalbinè įranga šilumos nuostoliams ị aplinką nustatyti su $\pm 1,5 \%$ neapibrèžtimi.

Šio įrenginio naudingumo koeficiento įvertinimo išplèstinè neapibrèžtis sudaro $\pm 2 \%$ ir visiškai atitinka standarto [5] keliamus reikalavimus. Todèl, reikalui esant, šis irenginys gali būti naudojamas vertinti Lietuvos gamintojų šildymo įrenginių atitikties reikalavimus. Nors tokie reikalavimai dabar Lietuvoje nèra taikomi, bet kitos Europos šalys saviems gaminamiems ir iš kitų šalių importuojamiems katilams jau taiko šiuos reikalavimus.

\section{Skaitinis modeliavimas}

Mažos galios kietojo biokuro katiluose vienu svarbiausių parametrų, lemiančių kuro visišką sudegimą, yra degimo produktų ir oro srautų, tiekiamų degimui, efektyvus maišymasis visose kuro degimo stadijose. Kadangi galutinis lakiųjų dujinių produktų sudeginimas vyksta degimo kameroje, tiekiant antrinį orą buvo siekiama nustatyti antrinio oro įtraukimo i degimo kamerą tinkamiausią vietą ir ịsiurbiamo oro kiekį. Modeliavimas atliktas keičiant antrinio oro tiekimo vietas esant natūraliai traukai. Oro srautų temperatūra buvo priimama lygi aplinkos temperatūrai. Kiti 2 svarbūs parametrai - reikiama temperatūra degimo zonoje ir efektyviam sudegimui reikalingas laikas - nebuvo nagrinejjami.

Modeliavimui pasirinktas kietuoju biokuru kūrenamo katilo natūralios traukos degimo kameros supaprastintas dvimatis (2D) modelis (3 pav.). Skaičiavimui buvo panau-

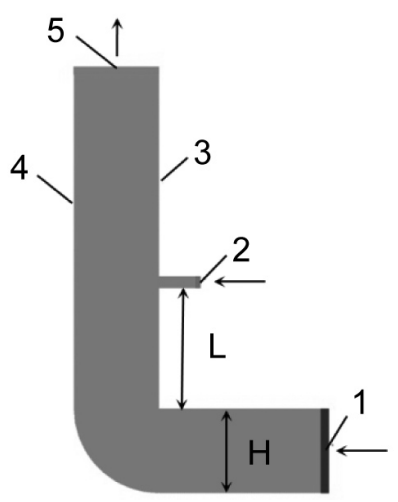

3 pav. Kietuoju biokuru kūrenamo katilo natūralios traukos degimo kameros supaprastintas dvimatis (2D) modelis: 1 - pirminio oro ir degimo produktu j̇ekejjimas; 2 - antrinio oro j̨tekejimas; 3 - priekinè vertikalios kanalo dalies sienelè; 4 - užpakalinè vertikalios kanalo dalies sienelè; $\mathrm{L}$ - antrinio oro j̨tekejjimo atstumas nuo vertikalaus kanalo pradžios, $\mathrm{H}$ - pirminio oro ir degimo produktų jtekejjimo kanalo aukštis 
2 lentelè. Tyrimams naudoto kuro parametrai

\begin{tabular}{|c|c|c|c|c|}
\hline \multirow{2}{*}{ Parametras } & \multicolumn{2}{|c|}{ Medienos granulès } & \multicolumn{2}{|r|}{ Uosio malkos } \\
\hline & Vertè & Išplèstinė neapibrèžtis $\pm \%$ & Vertè & lšplèstinè neapibrèžtis $\pm \%$ \\
\hline Sauso kuro viršutinis šilumingumas kJ/kg & 19863 & 0,33 & 19433 & 1,31 \\
\hline Drègno kuro apatinis šilumingumas kJ/kg & 17084 & 0,605 & 16478 & 1,48 \\
\hline Peleningumas $\%$ & 0,79 & 0,05 & 1,35 & 0,38 \\
\hline Visuminès drègmès kiekis \% & 7,48 & 0,08 & 10,16 & 0,08 \\
\hline C (anglies) kiekis \% & 50,26 & 1,15 & 49,00 & 0,58 \\
\hline $\mathrm{O}$ (deguonies) kiekis \% & 42,75 & 0,34 & 42,81 & 0,31 \\
\hline $\mathrm{H}$ (vandenilio) kiekis \% & 5,88 & 0,43 & 5,84 & 0,33 \\
\hline $\mathrm{N}$ (azoto) kiekis \% & 0,18 & 0,32 & 0,27 & 0,28 \\
\hline $\mathrm{S}$ (sieros) kiekis \% & $<0,01$ & - & $<0,01$ & - \\
\hline
\end{tabular}

dota ANSYS FLUENT v.14.0 kompiuterinès skysčių dinamikos programa ir standartinis $\mathrm{k}-\varepsilon$ turbulentiškumo modelis.

Kanalo matmenys pasirinkti artimi realios degimo kameros matmenims: pirminio oro ir degimo produktų itekejjimo kanalo aukštis - 0,15 m, ilgis - 0,6 m; antrinio oro itekejjimo plyšio aukštis - 0,02 m; vertikalios kanalo dalies plotis - 0,15 $\mathrm{m}$ ir ilgis - 0,6 m. Priimta, kad slègis ittekejjime lygus atmosferos slègiui, slègis ištekejjime iš degimo kameros esant natūraliai traukai pagal eksperimentinius duomenis sudaro apie $30 \mathrm{~Pa}$. Antrinio oro tiekimo angos buvo išdèstomos skirtingame aukštyje nuo įtekejjimo ir skirtingose kanalo sienelèse - priekinèje ir galinèje, atsižvelgus ị pagrindinio srauto krypti.

\section{TYRIMO REZULTATAI}

\section{Eksperimentiniai rezultatai}

Eksperimentiniai efektyvumo ir emisijų i aplinką tyrimai buvo atliekami skirtingais principais veikiančiuose $\sim 25 \mathrm{~kW}$ galios vandens šildymo katiluose, kūrenamuose medienos granulèmis ir malkomis, esant nuolatinei vardinei šiluminei apkrovai. Tyrimui buvo pasirinkti 4 šiuo metu ganètinai plačiai eksploatuojami periodiškai medienos kuru įkraunami katilai. Pagal deginimo principą du iš šių katilų buvo apatinio degimo katilai (4a, b pav.), kurių vienas su natūralia, kitas su priverstine trauka, ir vienas atvirkštinio degimo katilas (4c pav.). Palyginimui pasirinktas katilas su nuola-

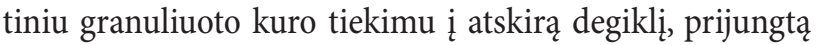

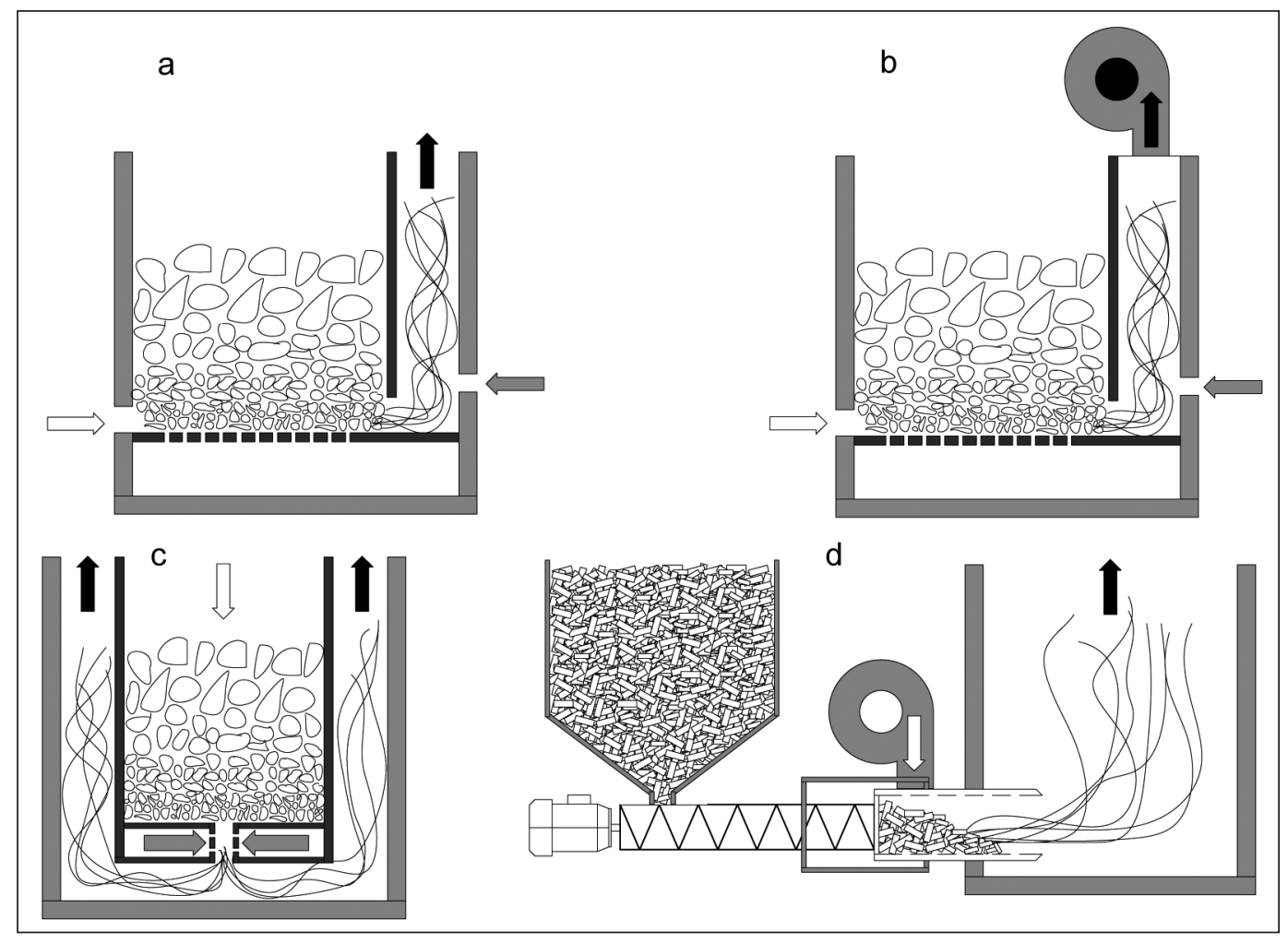

4 pav. Tirtų katilų schemos: a - apatinio degimo su natūralia trauka; $b$ - apatinio degimo su priverstine trauka; c-atvirkštinio degimo; $d$-su granulių degikliu; $\longrightarrow$ pirminis oras, $\longrightarrow$ antrinis oras, $\Rightarrow$ dūmų ištekejjimas 
prie kietajam kurui skirtos degimo kameros (4d pav.). Pastaroji deginimo technologija turi aiškių pranašumų, tačiau reikalauja specialiai paruošto kuro.

Tyrimų metu buvo naudotas kuras, kurio sudèties, šiluminingumo, peleningumo ir drégnumo tyrimo rezultatai pateikti 2 lentelëje.

Kaip matyti iš 2 lentelëje pateiktų duomenų, medienos granulių ir malkų medienos sudètis bei kiti parametrai buvo beveik analogiški.

(5-7) pav. pateikti visų keturių katilų $\mathrm{CO}_{2}, \mathrm{CO}, \mathrm{C}_{\mathrm{x}} \mathrm{H}_{\mathrm{y}}$ koncentracijų palyginimai katilams veikiant vardine galia. Periodiškai pakraunamų katilų teršalų emisijų kiekiai buvo vertinami pagal dviejų ikrovų degimo periodus.
Pagal $\mathrm{CO}_{2}$ reikšmes galima spręsti apie įrenginio degimo sureguliavimo ir veikimo tinkamumą. Todèl šis parametras buvo naudojamas vietoj oro pertekliaus koeficiento ar deguonies koncentracijos matavimų. $\mathrm{CO}_{2 \max }$ medienos kurui deginant be oro pertekliaus turètų būti apie 19,2 \% [9].

Kaip matyti 5 pav., granuliuotą kurą deginančio katilo $\mathrm{CO}_{2}$ koncentracija viso degimo metu išsilaiko apytikriai $12 \pm 1 \%$. Tai lemia granuliuoto kuro kokybè bei valdomas jo ir oro diegimo tiekimas ị degiklį. Granules deginančio katilo $\mathrm{CO}_{2}$ koncentracijos svyravimai atsiranda tik dèl to, kad kuras į degikli yra tiekiamas tam tikrais intervalais. Patiekus naują kuro dozę, $\mathrm{CO}_{2}$ koncentracija staigiai padidèja.

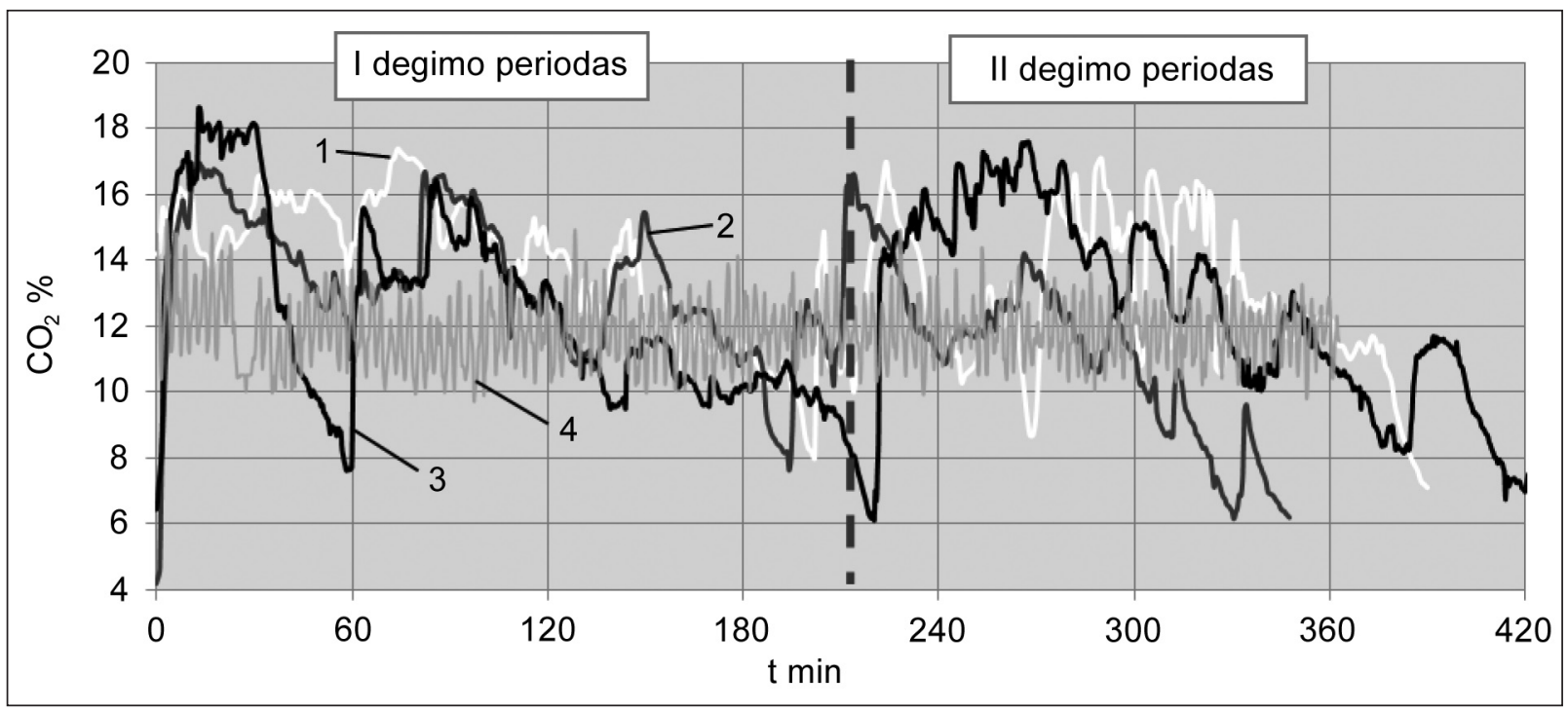

5 pav. Skirtingo veikimo katilų $\mathrm{CO}_{2}$ koncentracijų kitimo palyginimas: 1 - atvirkštinio degimo; 2 - apatinio degimo su natūralia trauka; 3 - apatinio degimo su priverstine trauka; 4 - granules deginančio katilo

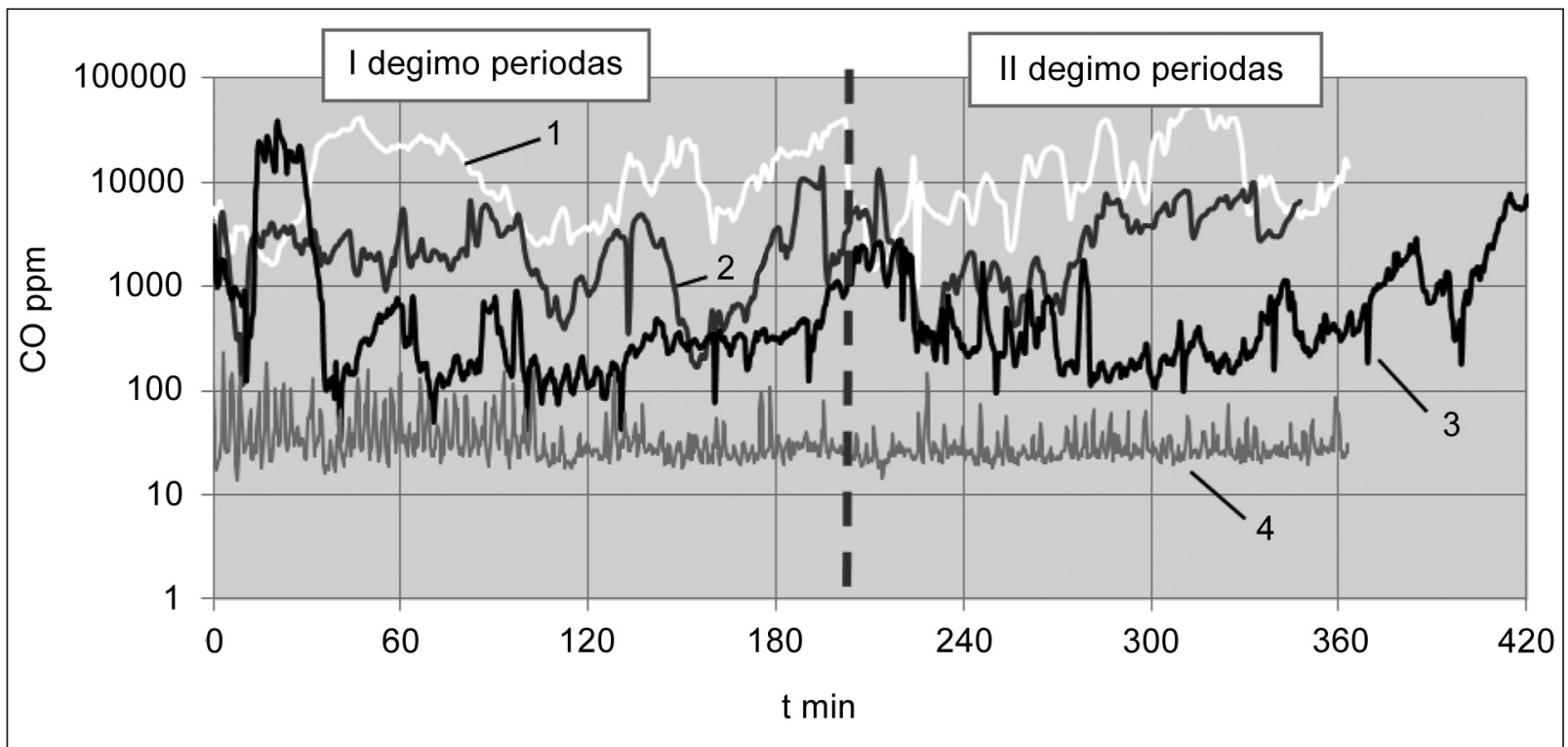

6 pav. Skirtingo veikimo katilų C0 koncentracijų kitimo palyginimas: 1 - atvirkštinio degimo; 2 - apatinio degimo su natūralia trauka; 3 - apatinio degimo su priverstine trauka; 4 - granules deginančio katilo 


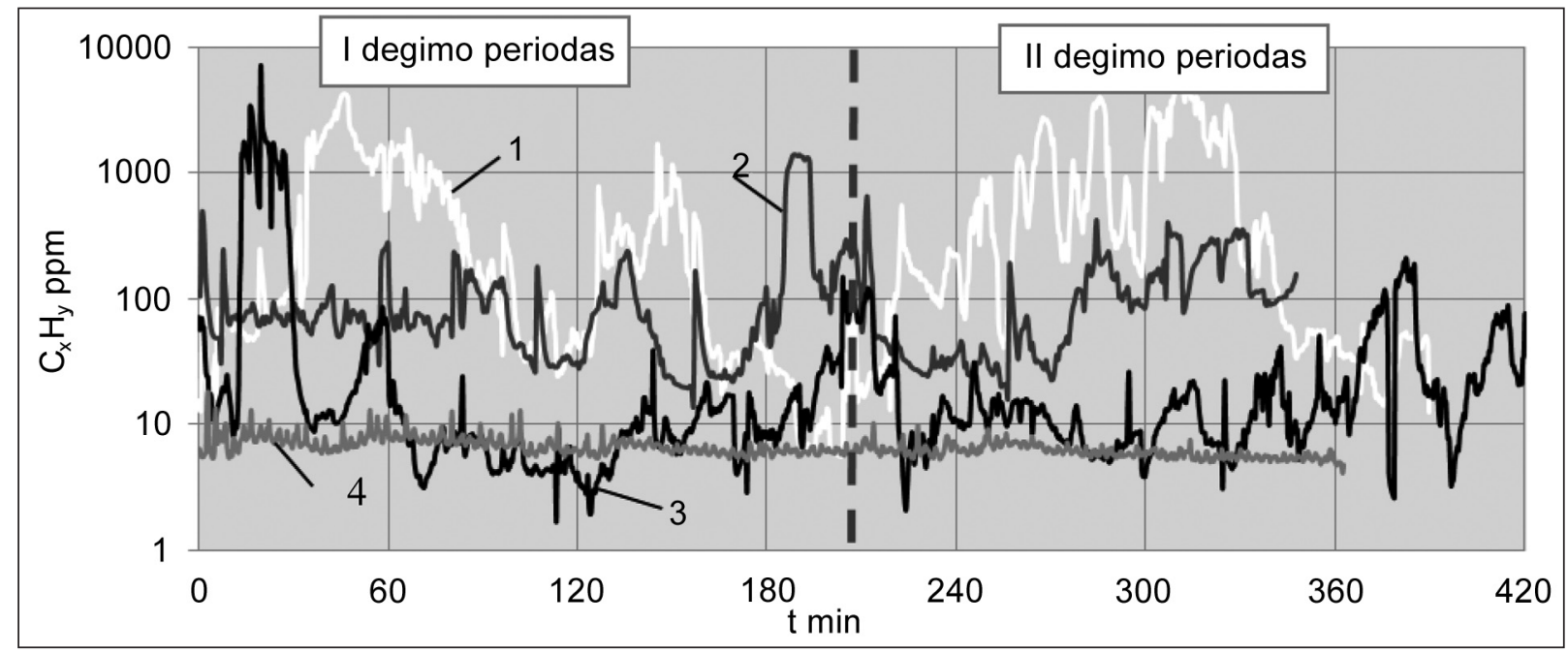

7 pav. Skirtingo veikimo katilų $\mathrm{C}_{\mathrm{x}} \mathrm{H}_{\mathrm{y}}$ koncentracijų kitimo palyginimas: 1 - atvirkštinio degimo; 2 - apatinio degimo su natūralia trauka; 3 - apatinio degimo su priverstine trauka; 4 - granules deginančio katilo

Periodiškai ¡̇kraunamuose katiluose stebimas didelis $\mathrm{CO}_{2}$ koncentracijos kitimas rodo, kad ịkrovos degimas nèra tolygus. Labiausiai $\mathrm{CO}_{2}$ padidejja, ịkrovus naują kuro ikrovą ir gerai įsidegus kurui. Tuo metu $\mathrm{CO}_{2}$ koncentracija pakyla beveik iki maksimalios vertès ir viso degimo metu mažèja, labai netolygiai kisdama. Priklausomai nuo katilo konstrukcijos kurui išdegus, $\mathrm{CO}_{2}$ koncentracija nukrenta iki 6-8 \%. Staigius $\mathrm{CO}_{2}$ koncentracijos padidejjimus ir sumažèjimus sukelia netolygus ịkrovos degimas, kintant jos struktūrai ir pasipriešinimui įkrovai sukrentant bei netolygiai pritekant orui.

Tačiau visų tipų katilų išskiriamų $\mathrm{CO}_{2}$ koncentracijų vidurkiai skiriasi ne itin daug - apie 1,5\%. Vis dèlto atvirkštinio degimo katilo ir apatinio degimo katilo su priverstine trauka degimo periodai yra ilgiausi. Pastarajam katilui būdingas akivaizdus $\mathrm{CO}_{2}$ padidèjimas pradiniame degimo periodo trečdalyje susietas su intensyviu degimu, dèl kurio $\mathrm{CO}_{2}$ beveik pasiekia maksimalias vertes.

Kaip ir buvo galima numanyti, mažiausios $\mathrm{CO}$ koncentracijos (6 pav.) nustatytos katile, deginančiame granuliuotą kurą. Tai lemia kokybiškas kuras ir tinkamai sureguliuotas kuro ir oro degimui tiekimas.

Apatinio degimo katilo su priverstine trauka CO koncentracijos labai padidejja pradiniu ịkrovos ịsidegimo metu, tai lemia žemoka degimo kameros temperatūra. Tačiau degimo kameroje padidejus temperatūrai iki darbinio lygio, CO koncentracijos labai sumažěja ir tolimesnius koncentracijų pokyčius lemia ardyno būklè. Bet koks kuro sukritimas ar oro trūkumas dèl išaugusio pasipriešinimo pratekèjimams didina CO koncentracijas, nes blogina degimui tiekiamo oro sąveiką su kuru ir jo degimo produktais. Be to, pasipriešinimo padidejimas kuro degimo zonoje esant natūraliai traukai padidina antrinio oro pritekẻjimą i zoną (bus toliau parodyta).

Apatinio degimo katilas su natūralia trauka išskiria daugiau CO nei analogiškas katilas su priverstine trauka. Tačiau pradiniu momentu (dèl mažesnio tiekiamo degimui oro kiekio) temperatūra degimo kameroje pasiekiama aukštesnè ir CO nedideja taip intensyviai, kaip katile su priverstine trauka. Atvirkštinio degimo katilo CO išmetimai yra didžiausi, nors toks deginimo principas turètų leisti pasiekti geresnių efektyvumo rodiklių ir mažesnių teršalų emisijų. Iš dalies sudegę produktai dūmuose atsiranda dèl šiu pagrindinių priežasčių - netinkamo oro tiekimo degimui arba jo trūkumo ir žemos temperatūros kūrykloje.

7 pav. pateiktos angliavandenilių $\left(\mathrm{C}_{\mathrm{x}} \mathrm{H}_{\mathrm{y}}\right)$ koncentracijų kitimo kreives. Kaip matyti iš šių duomenų, $\mathrm{C}_{x} \mathrm{H}_{\mathrm{y}}$ kon-

3 lentelè. Skirtingo veikimo tipo katilų vidutinės taršos ir efektyvumo vertès

\begin{tabular}{c|c|c|c|c|c}
\hline Katilo tipas & $\mathbf{C O}_{2} \%$ & $\mathbf{C O} \mathbf{p p m}$ & $\mathbf{C x H}_{\mathbf{y}} \mathbf{p p m}$ & $\begin{array}{c}\text { Kietosios dalelés } \\
\text { esant 10 \% } \\
\mathbf{0} \mathbf{~ m g} / \mathbf{m}^{3}\end{array}$ & $\begin{array}{c}\text { Naudingumo koefi- } \\
\text { cientas \% }\end{array}$ \\
\hline $\begin{array}{c}\text { Granules deginantis katilas } \\
\begin{array}{c}\text { Apatinio degimo katilas su } \\
\text { priverstine trauka }\end{array}\end{array}$ & 11,81 & 36 & 6,6 & 21,5 & 89,8 \\
\hline $\begin{array}{c}\text { Apatinio degimo katilas su } \\
\text { natūralia trauka }\end{array}$ & 12,39 & 1508 & 77 & 75,4 & 84,8 \\
\hline Atvirkštinio degimo katilas & 13,41 & 2887 & 125,7 & 82,8 & 82,1 \\
\hline
\end{tabular}




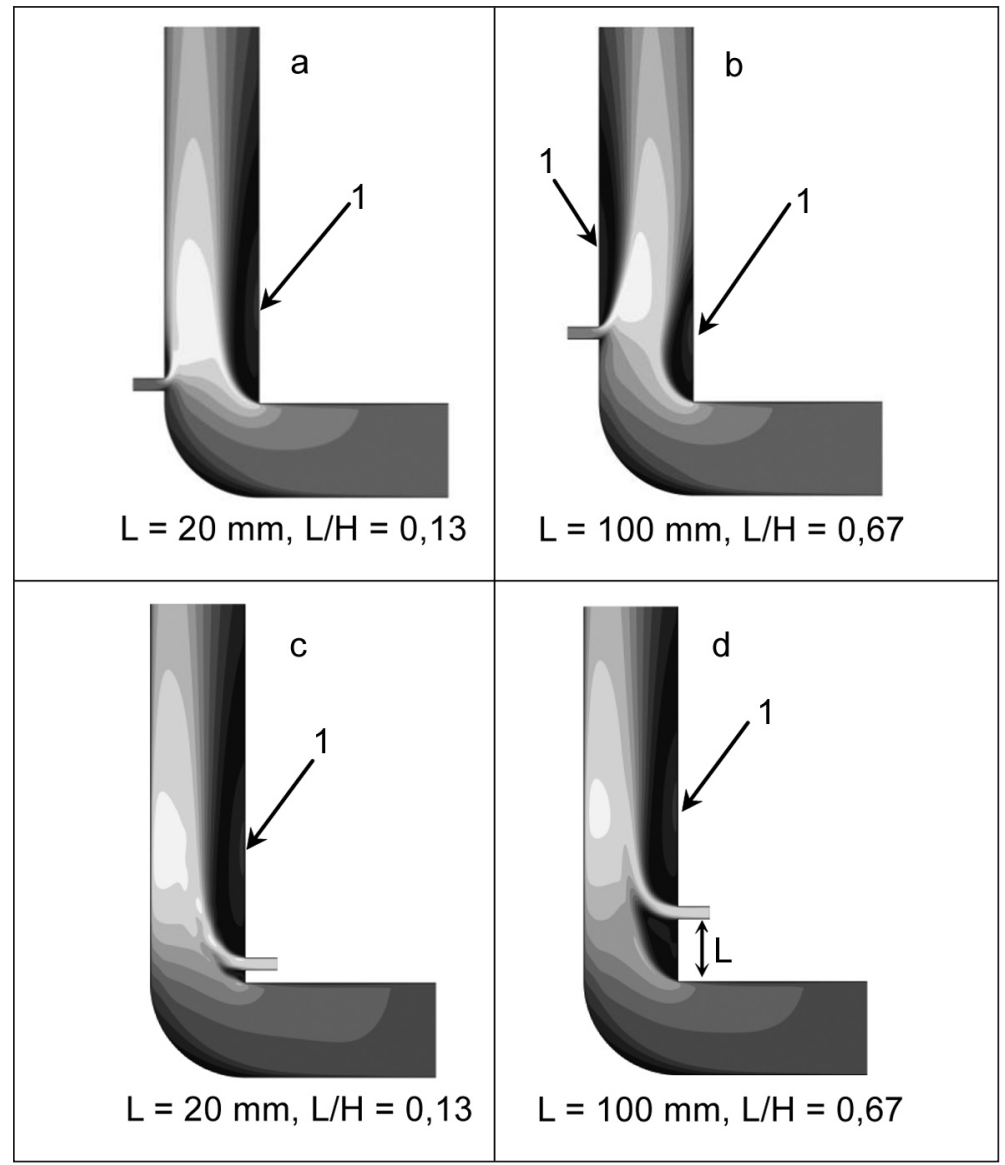

8 pav. Greičio pasiskirstymas, atsižvelgus į antrinio oro j̨tekejjimo atstumą (L) nuo posūkio kampo: $a$ ir $b$ - užpakalinè sienelè; c ir $d$ - priekinè sienelè, 1 - recirkuliacinè mažo greičio zona

centracijų kitimo tendencijos išlieka tokios pat kaip ir CO koncentracijų. Dèl anksčiau minètų priežasčių vèl matomas analogiškas koncentraciju išsisluoksniavimas. Atvirkštinio degimo katilo yra blogiausi rodikliai, o granuliuotą kurą deginančio katilo - geriausi.

Tyrimų rezultatų apibendrinimas, pateiktas 3 lentelëje, rodo, kad granulèmis kūrenamo katilo naudingumo koeficientas labai artimas $90 \%$ ir visu teršalu emisijos yra daug mažesnès nei katilų, periodiškai ikraunamu medienos kuru. Toks skirtumas atsiranda ne tik todèl, kad specialiai paruoštas medienos granulių kuras turi geresnes savybes, bet ir tai, kad degimo procesas tinkamiausiai sureguliuotas ir efektyviai valdomas. Palyginus su 1 pav. pateiktais rezultatais, galima teigti, kad naudojant tinkamai paruoštą kurą ir deginimo technologiją jau pasiekiamas naudingumo koeficiento lygmuo, ganètinai artimas prognozuojamai viršutinei ribai.

Kitų katilų, kūrenamų ịprastiniu medienos kuru, naudingumo koeficientai kinta $82-85 \%$, tačiau teršalų išmetimai daug didesni nei granulèmis kūrenamo katilo. Apatinio degimo katilas su priverstine trauka pasižymi geresnemis charakteristikomis nei katilas su natūralia trauka. Atvirkštinio degimo katilas reikalauja tobulinimo, pirmiausia, susieto su tinkamu antrinio oro tiekimu ir reikiamos tempe- ratūros palaikymu dujinimo proceso metu pagamintoms dujoms sudeginti. Pastaroji deginimo technologija yra pažangesnè, nes, tinkamai ją suderinus, leidžia dujinti ịvairios rūšies kurą ir efektyviai sudeginti pagamintas dujas atskirame degiklyje arba tiesiogiai tiekiant dujas ị katilo degimo kamerą.

\section{Skaitinio modeliavimo rezultatai}

Skaitinio modeliavimo rezultatai (8 pav.) rodo, kad antrinio oro ittraukimo intensyvumas ir greičio pasiskirstymas vertikalioje kanalo dalyje labai priklauso nuo to, kurioje sienelejje (priekinejje ar užpakalinëje) ir kurioje jų vietoje yra antrinio oro tiekimo angos. Visais atvejais pagrindinis atitekantis srautas, pertekeddamas ị vertikalų kanalą, dèl išcentrinių jègų poveikio yra „prispaudžiamas“ prie užpakalinès kanalo sienelès ir jo greitis ties ja yra didžiausias. Ši poveikị sustiprina srauto atitrūkimas ties priekinès sienelès kampu. Dèl šiu priežasčių antrinio oro įtraukimas slopinamas, kai ties priekine sienele įtraukimas akivaizdžiai didèja (8 ir 9 pav.). Itraukiama ị pagrindinị srautą oro srovè formuoja hidrodinaminę kliūtị, kuri sukelia pagrindinio srauto krypties ir greičio pasiskirstymo skerspjūvyje pokyčius. Už šios kliūties pradeda formuotis recirkuliacinio tekèjimo zona, kuri laipsniškai besiplèsdama 


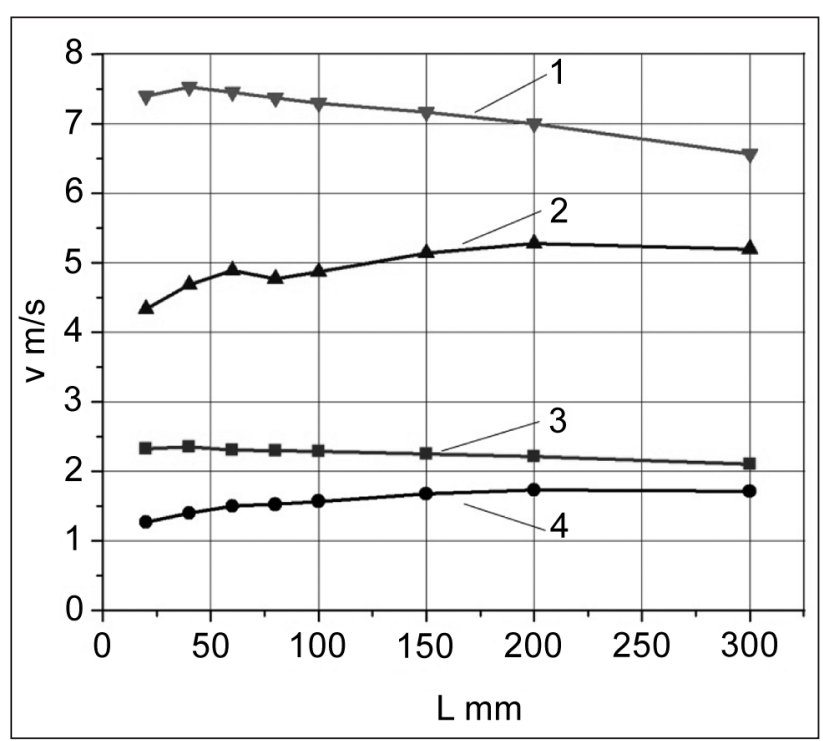

9 pav. Vidutinis antrinio oro j̨tekẻjimo greitis (v), atsižvelgus i jo j̇tekëjimo atstumą (L) nuo kanalo posūkio: 1 ir 3 - įtekèjimas iš priekinès sienelès; 2 ir 4 - j̇ekejimas iš užpakalinès sienelès; 1 ir 2 - esant $30 \mathrm{~Pa}, 3$ ir 4 - esant $3 \mathrm{~Pa}$ slègiui ištekèjime

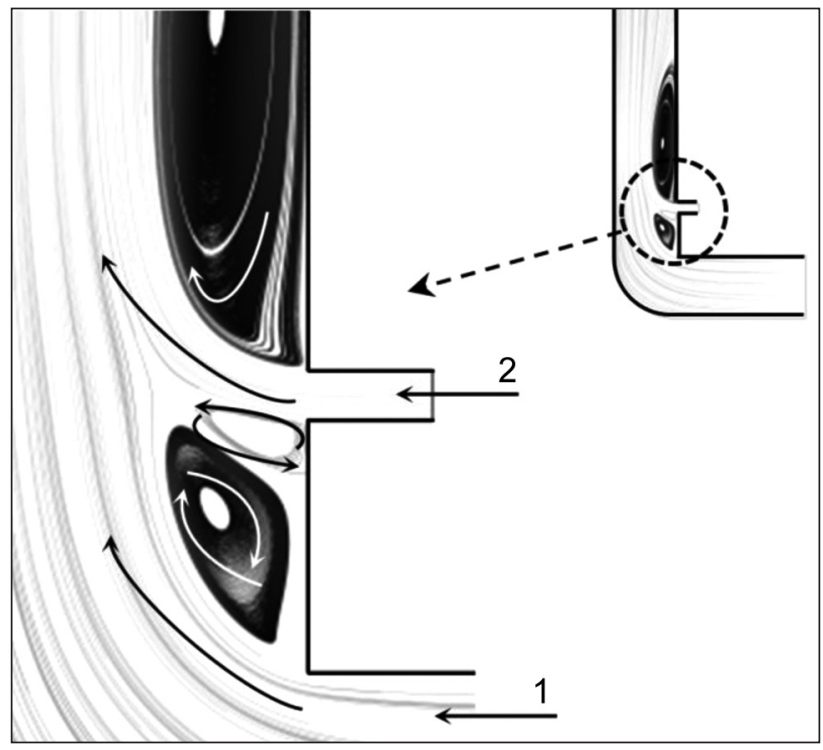

10 pav. Antrinio oro srovès, ištekančios iš angos priekinèje sienelèje, aplinkoje susiformuojanti sūkurių struktūra esant $\mathrm{L} / \mathrm{H}=0,67: 1$ - pirminio oro ir degimo produktų itekejjimas; 2 - antrinio oro j̨tekèjimas

perstumia pagrindinị srautą link priekinès sienelès. Kaip matyti $8 \mathrm{a}$ ir $8 \mathrm{~b}$ pav., esant santykiui $\mathrm{L} / \mathrm{H}=0,67$ greičio pasiskirstymas igauna pavidalą, parodytą $8 \mathrm{~b}$ pav., kuris išsilaiko tolinant antrinio oro įtekèjimą nuo posūkio kampo. Pagrindinio srauto poslinkis link priekinès sienelès lemia prie jos atitrūkusio srauto recirkuliacinę zoną. Nuo L/H = 0,67 šios zonos aukštis labai gerai koreliuoja su antrinio oro ịtekèjimo aukščiu. Taigi antrinio oro įtraukimo greitis nuo užpakalinès sienelès pusès visuomet yra iš esmės mažesnis nei nuo priekinès sienelès ( 9 pav.), bet greičio pasiskirstymas vertikaliame kanale pasiekiamas tolygesnis. Tai rodo geresni pagrindinio srauto ir ịtraukiamos oro srovès susimaišymą.

Antrinio oro sroves, itraukiamos nuo priekinès sienelès, ir pagrindinio srauto sąveikos dinamiką atspindi 8-10 pav. pateikti skaičiavimo rezultatai. Matyti, kad tokiu atveju antrinio oro srovė yra tarp dviejų ganètinai stabilių sūkurių, kurių apatinį formuoja srauto atitrūkimas aptekant kanalo posūkio kampą ir ištekanti oro srové, kaip kliūtis pagrindiniam srautui (10 pav.).

Antrinio oro ịtekèjimo angas įrengus priekinëje sienelejje ( $8 \mathrm{c}$ ir $8 \mathrm{~d}$ pav.), susidaro daug palankesnès sąlygos antriniam orui ittekèti. Be to, srove mažiau besimaišydama su pagrindiniu srautu nuteka link užpakalinès sienelès, o recirkuliacinè zona prie priekinès sienelès akivaizdžiai padidèja. Šiuo atveju srauto asimetrija vertikaliame kanale labai padidèja ir išsilaiko stabili nepriklausomai nuo antrinio oro angos atstumo nuo kanalo pradžios. Taip pat srovei ištekant iš priekinès sienelès, vertikalaus kanalo pasipriešinimas padidèja ir esant nuolatinei traukai bendras debitas sumažèja iki $10 \%$.

Pateikti duomenys rodo, kad skaitinio modeliavimo taikymas leidžia numatyti arba iš dalies išspręsti daugeli svarbiu uždavinių, susietu su degimo kameros konstrukcija, antrinio oro tiekimu ir efektyviu srautų susimaišymu. Siekiant tikslinti skaitinị modeliavimą būtina prijungti cheminių reakcijų ir šilumos sklidimo (radiacija ir konvekcija) lygčių sistemas.

\section{IŠVADOS}

1. Mažos ir vidutinės galios vandens šildymo katilai su granuliuoto medienos kuro degikliais gali užtikrinti ne mažesnị kaip $90 \%$ naudingumo koeficientą ir mažus $\mathrm{CO}, \mathrm{C}_{\mathrm{x}} \mathrm{H}_{\mathrm{y}}$ bei kietujjų dalelių emisijas ị aplinką. Tokia biokuro deginimo technologija gali būti orientyras pertvarkant šildymo sistemas su ịvairios galios katilais.

2. Malkų medienos panaudojimas periodiškai įkraunamuose katiluose (nepriklausomai nuo jų tipo: apatinio, viršutinio, ar atvirkštino degimo) efektyvumo didinimas ir teršalų emisijų i aplinką mažinimas turi būti grindžiamas eksperimentiniais ir skaitiniais tyrimais pagrịstu pirminio ir antrinio oro tiekimo it degimo zonas nustatymu, tinkamo temperatūros režimo išlaikymu ir reikiamos kuro buvimo degimo zonoje trukmès užtikrinimu. Labiausiai oro tiekimo reguliavimas reikalingas įsidegant naujai įkrautam kurui ir baigiantis ịkrovos degimui. Antrinio oro priverstinis tiekimas leidžia pasiekti geresnių veiksmingumo rodiklių.

3. Atvirkštinio deginimo principas, kuriuo siekiama išnaudoti kuro dujinimo ir gautų dujų deginimo pranašumų, leidžia pasiekti geresnių efektyvumo rodiklių ir mažesnių teršalu emisijų, bet reikalauja tinkamos konstrukcijos degimo kameros ir efektyvaus antrinio oro tiekimo užtikrinant 
visišką sudegimą. Apskritai kuro dujinimas yra perspektyvus metodas, nes galima panaudoti ịvairios rūšies biokurą dujinant $\mathrm{ji}$ atskiruose ịrenginiuose ir deginant ịprastinių ịrenginių degimo kamerose.

4. Siekiant teikti vartotojams objektyvią informaciją apie gaminamų katilų, kūrenamų biokuru, charakteristikas, būtina nustatyti efektyvumo ir išmetamų teršalų reikalavimus pagal Europoje galiojančius standartus [5,6]. Atitiktis šiems reikalavimams turi būti patvirtinama trečiosios šalies atitinkamu ženklinimu. Biokurą būtina sertifikuoti, nes jo sudètis ir kokybiniai rodikliai turi esminị poveikị degimo proceso efektyvumui.

\section{PADÉKA}

Tyrimą finansuoja Lietuvos mokslo taryba (sutarties Nr. ATE-02/2012).

Gauta 20130320

Priimta 20130508

\section{Literatūra}

1. Kuro ir energijos balansas 2011. Lietuvos statistikos departamentas. Vilnius, 2012.

2. Obernberger I. The present state and future development of industrial biomass combustion for heat and power generation. Proceedings of ASME-ATI-UIT 2010 Conference on Thermal and Environmental Issues in Energy Systems, Sorrento, Italy, 16-19 May 2010.

3. Obernberger I., Thek G. Combustion and gasification of solid biomass for heat and power production in Europe - state-of-the-art and relevant future developments. Proceedings of the 8th European Conference on the Industrial Furnaces and Boilers, Vilamoura, Portugal, April 2008.

4. Obernberger I., Christoph M. Survey on the Present State of Particle Precipitation Devices for Residential Biomass Combustion with a Nominal Boiler Capacity up to $50 \mathrm{~kW}$ in IEA Bioenergy Task32 Member Countries. Graz, Austria, December 2011.

5. LST EN 303-5: 2012. Šildymo katilai. 5 dalis. Rankomis ir automatiškai pakraunami kieto kuro šildymo katilai, kurių atiduodamoji šiluminé galia iki 500 kW. Terminijos reikalavimai, bandymai ir ženklinimas.

6. LST EN 15359: 2012. Kietasis atgautasis kuras. Techniniai reikalavimai ir klasès.

7. European Wood-Heating Technology Survey: An Overview of Combustion Principles and the Energy and Emissions Performance Characteristics of Commercially Available Systems in Austria, Germany, Denmark, Norway, and Sweden. Final Report 10-01. Albany, New York: New York State Energy Research and Development Authority, April 2010.
8. Tissari J., Lyyraanen J., Hytoonen K. Fine particle and gaseous emissions from normal and smouldering wood combustion in a conventional masonry heater. Atmospheric Environment. 2008. Vol. 42. Issue 34. P. $7862-$ 7873.

9. Murari M. R., Kenny W. C. An experimental study of combustion and emissions of biomass briquettes in a domestic wood stove. Applied Energy. 2012. Vol. 99. P. 206-212.

Tomas Vonžodas, Nerijus Pedišius, Mantas Valantinavičius

\section{INVESTIGATION OF PERFORMANCE PARAMETERS OF LOW CAPACITY WATER BOILERS BURNING BIOFUEL}

\section{Summary}

Efficiency and emissions of small-scale water boilers operating on various principles and fired with wood fuel were experimentally investigated. It is shown that usage of wood pellets in small-scale appliances allows to achieve at least $90 \%$ efficiency and minimum emissions into the environment. Use of wood logs in manually stoking boilers highly depends on proper combustion chamber design, selection location of the secondary air supply and support of suitable temperature regime.

The air supply adjustment is mostly needed at the ignition stage of newly charged fuel and at the end of charge combustion. The under-burning (inverse) combustion principle, which allows to use benefits of the fuel gasification and combustion of formed gas, leads to better efficiency and lower emissions, but requires proper design of combustion chambers and efficient supply of secondary air to ensure complete combustion.

The numerical modeling of secondary air supply to the combustion chamber of under-burning type at natural draft conditions was performed. This modeling allows to select the most suitable air supply locations, furnace design and to analyze flow mixing processes.

Key words: solid biofuel, wood fuel, water heating boilers, efficiency, pollution 
Томас Вонжодас, Нериюс Пядишюс,

Мантас Валантинавичюс

\section{ИССЛЕДОВАНИЕ РАБОЧИХ ПАРАМЕТРОВ}

ВОДОНАГРЕВАТЕЛЬНЫХ КОТЛОВ МАЛОЙ МОЩНОСТИ, СЖИГАЮЩИХ БИОТОПЛИВО

Резюме

Экспериментально исследована эффективность и выбросы загрязнений в окружающую среду различного типа водонагревательных котлов малой мощности, сжигающих древесное топливо. Показано, что использование гранулированного топлива в котлах малой мощности позволяет достичь эффективности не менее 90 \% и минимального уровня выбросов. Эффективность использования дров в периодически загружаемых котлах во многом зависит от конструктивного исполнения камеры сжигания, выбора места подачи вторичного воздуха и поддержания температурного режима. Регулировка подачи воздуха наиболее важна на начальной стадии возгорания загруженного топлива стадии его выгорания. Принцип придонного сжигания, в котором используются достоинства газификации топлива и дальнейшего его сжигания, позволяет достичь лучших показателей эффективности и выбросов. Однако, этот метод требует повышенного внимания исполнению конструкции камеры дожигания газифицированного топлива и эффективной подачи вторичного воздуха для обеспечения полного сгорания.

В работе также представлены результаты численного моделирования вовлечения вторичного воздуха в основной поток при наличии натуральной тяги в котлах с придонным сжиганием. Моделирование позволяет подобрать наиболее подходящее расположение мест подачи вторичного воздуха, конструкцию камеры сжигания, а также детально анализировать процессы смешивания потоков.

Ключевые слова: биотопливо, древесное топливо, водонагревательные котлы, эффективность выбросов 